Educational Research for Social Change (ERSC)

Volume 7 No. 2, September 2018

pp. 74-86

ersc.nmmu.ac.za

ISSN: 2221-4070

\title{
Engaging critical emancipatory research as an alternative to mitigate school violence in South Africa²
}

\author{
Bekithemba Dube \\ University of the Free State \\ bekithembadube13@gmail.com \\ Dipane Hlalele \\ University of KwaZulu-Natal \\ hlaleled@ukzn.ac.za
}

\begin{abstract}
In this theoretical paper, we contribute to ongoing narratives that attempt to mitigate and curb school violence. We do this by critiquing school relations through the lens of critical emancipatory research. Critical emancipatory research has the impetus to map skewed relations that exacerbate school violence in South African schools. In order to achieve our aim, we highlight various principles of critical emancipatory research that position the theory so that it relates to rebuilding school safety to achieve better schools for all stakeholders. The principles of social justice and social transformation, and the necessity to eliminate false consciousness, are discussed as critical elements of mitigating school violence. The article argues that critical emancipatory research, when it is used to frame relationships within the school milieu, has the impetus to forge new dimensions of, and responses to, conflict resolution-and to lessen school violence.
\end{abstract}

Keywords: critical emancipatory research; school violence; safer school; healthy relations.

Copyright: @ 2018 Bekithemba Dube and Dipane Hlalele

This is an open access article distributed under the terms of the Creative Commons Attribution Non-Commercial License, which permits unrestricted non-commercial use, distribution, and reproduction in any medium, provided the original author and source are credited.

Please reference as: Dube, B. \& Hlalele, D. (2018). Engaging critical emancipatory research as an alternative to mitigate school violence in South Africa. Educational Research for Social Change, 7(2), 74-86. http://dx.doi.org/10.17159/2221-4070/2018/v7i2a5

\section{Introduction}

School violence is a social pathology that can no longer be ignored. It has rendered some schools unsafe zones for both educators and learners. School violence in South Africa has various causes, however, one of the underlying causes that has not been problematised in school violence narratives is the nature of school relationships between teachers, learners, and other stakeholders such as parents (Mncube \& Harber, 2013; Nthate, 2017). Unhealthy relationships in school matters manifest

2 Ethical clearance number: UFS-HS 
in school violence; incidents of school violence provide proof of unhealthy school relationships. In the Eastern Cape, a teacher was allegedly killed by a learner when the learner failed (Mashaba, 2018). In Mdlamfe High School in Esikhawini, in the Richards Bay district, teachers subjected learners to violent behaviour (Wicks, Olifant, \& Naidoo, 2017). Owing to unhealthy relationships, some schools become war zones, street-fighting centres, and, in some cases, murder scenes (Francia \& Edling, 2017; Langhout \& Annear, 2010). Given the context and the nature of school violence, the South African Council of Churches has claimed that South African schools are becoming "mafia schools" (Strydom, 2017); this claim was reiterated by Cyril Ramaphosa when he was the vice president of both the African National Congress and the Republic of South Africa (Stoddard, 2017). In this context, we join hands with other scholars to problematise unhealthy relationships by engaging critical emancipatory research (CER) as a theory to frame relations among school stakeholders in order to combat school violence.

\section{School Violence in South Africa: Mapping the Need for Critical Emancipatory Research}

Various researchers (Lazarus, Khan, \& Johnson, 2012; Moen \& Steyn, 2016; Ncontsa \& Shumba, 2013; Ngqela \& Lewis 2012; van der Westhuizen \& Maree, 2009) have gone to great lengths to expose the underlying trajectories that have led to the rise of school violence in South Africa. While it may not be the jurisdiction of this article to repeat the observations made by other scholars, it is pertinent to point out that, regrettably, serious problems continue to exist at schools regarding the level and quality of educators' work, the attitudes of both educators and learners (de Clercq, 2013), and drug and weapon use. In the Free State province of South Africa, in 2016 alone, there were 753 cases of school violence characterised by the use of dangerous weapons such as guns, knives, and knobkerries (Department of Basic Education, 2016).

In addition to using the presence of weapons as an indicator of the potential for violence, various studies (Abramovay \& Gracas Rua, 2002; Burton \& Leoschut, 2013; Davids \& Waghid, 2016; Eisenbraun, 2007; Edberg, Shaikh, Rimal, Rasool, \& Mthembu, 2017; Gittins, 2006; Gomes \& Pereira, 2007; Grobler, 2018; Kindiki, 2009) have indicated that the breakdown of relations between teachers and teachers, between learners and learners, and, in some cases, between learners and teachers, contributes to the escalation of violence in schools. Wicks (2015) reported that a learner died from injuries sustained during fighting at school, which may have been caused by a breakdown of communication between the deceased and the other learner involved. Chawane (2018) reported that a teacher was beaten by two learners after a breakdown of communication about the use of a cell phone; Chawane supplied a video showing the two learners attacking the teacher. Head (2018) reported that a teacher was attacked by a learner in class who used a book as a weapon to attack the teacher. Jordaan (2018) said that, in the year 2017, Limpopo province recorded about 358 cases relating to learners attacking other learners. We argue that learners and teachers who resort to the use of force and weapons indicate communication breakdown, loss of trust, and anger, which are among the causes of school violence. Having noted these incidents of communication breakdown, it is clear that there is a need for healthy relations in schools, and our argument is that using CER to frame relations in schools will enhance communication while, at the same time, reduce violence.

In an attempt to acknowledge and recognise the need to address the scourge of school violence, Minister Motshekga, Minister of Basic Education, lamented the "unsettling safety levels in schools" (cited in Hweshe, 2011, I. 2), the National Professional Teachers Organisation of South Africa (NAPTOSA) claimed that school violence is "under-reported," and the Federation of School Governing Bodies of South Africa (FEDSAS) blamed parents for not assisting in curbing school violence (as cited in Dlamini, 2018a, 2018b). Against the backdrop of the 2018/2019 Education budget vote, the South African Democratic Teachers Union (SADTU) commented as follows: 
It is unfortunate that the budget vote did not make any allocation for school safety. We regard safety in schools as crucial towards the delivery of quality public education. Our schools are plagued by violence among learners, teacher attacks, abuse and gangsterism. We would like to see the DBE [Department of Basic Education] leading in ensuring safety in our schools and not allowing this matter to be in hands of the security cluster only. (2018, p. 1)

The high level of school violence in one province indicates the challenge we, as educationists, face to transform schools into safe havens and to achieve high quality education for all. The question is, how can this transformation be achieved in schools? We submit that relations framed in CER can contribute to the desired change. In the following section, we highlight the framework, which, for the purpose of this article, acts as a strategy to address school violence.

\section{Critical Emancipatory Research: Contextualising Its Relevance for Violence Narratives}

Various assumptions are made in relation to the origins of CER, however, scholars agree that it is an offshoot of critical theory of the Frankfurt School, which arose in Germany in 1923, and which was developed by Jürgen Habermas. Among explanations for the rise of CER is that of McKernan (2013), who believes that critical theory was first hinted at by Emmanuel Kant, a German philosopher, in 1871. McLaughlin (1999, p. 109) presented a different view, namely, that CER arose as a product of a "Marxist think tank founded by a wealthy son of a German millionaire, Mr Weil, who helped the Frankfurt School to create an innovative brand of philosophically oriented radical social science." Despite disagreements about who mooted the idea, CER is generally traced to the Frankfurt School for "Social Research established in 1923 at the University of Frankfurt and, in particular, to the works of Habermas, who was influenced by Marxist perspective on economic and social questions" (Schmidt, 2007, p. 51). In addition, Nkoane (2013, p. 99) noted that the Frankfurt School represented a left-wing group that had "philosophical roots in several traditions such as Marx's analysis of socio-economic conditions and class structure, Habermas's notion of emancipatory knowledge and Freire's transformative and emancipatory pedagogy." Its thrust, as Kingston (2007) proposed, was to find a solution to the crisis in Europe, in much the same way as we are attempting to end school violence in South African schools today.

In order to redress the contested terrain in Europe and, in particular, in Germany, the Frankfurt Scholars attempted to collaborate with philosophers, economists, and psychoanalysts (Wellmer, 2014) to enable, as Demirovic (2009) explained, participation that shaped the world into a better place for all. In order to achieve this ideal, there was a need to embrace strategies that challenged the preservation of an oppressive status quo, and to achieve social transformation by embracing social justice (Ngwenyama, 1991). The mandate of the Frankfurt Scholars was clear: to change oppressive structures by engaging in research. This research served as "cross-fertilization of barely inaugurated research methods and approaches" (Mendieta, 2005, p. 3) aimed at conscientising the populace, who had to discover their oppressed state and move towards derailing, unearthing, and castigating practices that have a negative bearing. The efforts of the Frankfurt Scholars through research did not go unnoticed, and led to most of the scholars being exiled (Wellmer, 2014). However, even this retaliation did not derail the mandate; to the contrary, the School grew in exile, especially under Max Horkheimer (McKernan, 2013). The struggle mandate was to problematise "historical and social conditions of crisis, and replace them with emancipatory ones" (Sinnerbrink, 2012, p. 370). The way CER shapes school relations is based on two observations that are pertinent to social transformation. First, (Ndlovu-Gatsheni, 2013) is of the view that school violence should not be normalised as a natural state of order. In fact, scholars must engage in intellectual journeys to problematise it, and to unearth and challenge unhealthy school relations because such relations produce a world order that is 
maintained through violence and deceit. Second, Akinsola (2010, p. 658) called for an "open debate on how to engage minds in a critical manner to effectively deal with the issue of school violence in high schools in South Africa." In short, CER is relevant for couching this article because it provides a theoretical basis for a view of planning that emphasises widespread public participation, sharing of information with the public, reaching consensus through public dialogue to improve relations rather than exercise of power, avoiding privileging of experts and bureaucrats, and replacing the model of the technical expert with one of the reflective planner (Argyris \& Schön, 1974).

While dialogue is not always easy and possible, it is desirable; thus, in relation to violence, we focus on three pertinent matters raised by CER scholars that can play a mitigating role in school violence. These matters are social justice, social transformation, and the elimination of false consciousness, through which we submit that schools and "societies can channel the energy of conflict into constructive rather than destructive channels" (Abu-Nimer, Khoury, \& Welty, 2007, p. 131) by cultivating deliberative encounters that alleviate the scourge of school violence (McDonald, 2013). In short, we agree with Mahlomaholo (2009), that CER seems to be one of the most potent means of creating conditions under which this distorted consciousness can be subverted-and a positive academic identity cultivated.

\section{Applying Principles of Critical Emancipatory Research to Mitigate School Violence}

In this section, we focus on four tenets of CER that underpin this theoretical paper, in an attempt to contribute to the ongoing discussion on how to mitigate school violence. We begin by highlighting various studies that used CER to improve various conditions. Chidarikire (2017) used CER in the context of a power struggle between peer counsellors based at rural and urban schools. By using CER to frame relations among counsellors, conflict was reduced and common ground, based on justice and equity, was found. In the same vein, Dube (2016) studied conflict among people with different religious standpoints by framing relations in CER. His study concluded that when relations are framed in social justice, hope, and respect of difference (the critical tenets of CER), CER has the impetus to minimise religious conflict and segregation. Nkoane (2012) conducted a study of the relationship between a researcher and the coresearchers, arguing that research centred in CER, and which emphasises social justice, has the potential to redress conflict in research. In addition, Msimanga (2017) conducted a study using CER to ensure effective communication among economics teachers. He argued that CER is critical in the academic space because it enables dialogue among teachers and learners on difficult economic concepts. He concluded that, if dialogue is underpinned by CER principles such as social justice, education and the learning environment become user friendly and benefit all educational stakeholders. Given these studies that used CER and yielded positive results, this paper, then, argues that CER, when used in the context of school relations, has the impetus to transform schools and make them safe places for learners. In this light, we discuss the principle of social justice, and show how it can contribute to safe schools.

\section{Social justice in school violence contestation.}

In any society where social injustice is evident, there is a likelihood of conflict, underdevelopment, and sometimes death (Dilworth-Anderson, Pierre, \& Hillard, 2012). Some schools, as social institutions, are characterised by a lack of justice. Consequently, a growing number of scholars question the extent to which schools are sited to promote social justice (Carlisle, Jackson, \& George, 2006; Hackman, 2005; Kaur, 2012; Malcolm et al., 2007). Social justice, the term used in this article, "concerns quality in the distribution of an education service, and it also concerns the nature of the service itself and the consequences for society through time" (Connell, 2012, p. 681). It is a learned response fostered by progressive human development and the need for dignity by every person in order to achieve an equal society (Brady, 2010). Echoing these sentiments, Traitler (2015) stated that social justice has the 
potential to encourage a move towards equality, and to foster the initiative of peace building and shared lives; with such an approach to framing schools' relations, afe schools can be achieved.

To achieve social justice, schools need to transform to ensure that they are safe zones for all stakeholders. In the Weimar Republic, in the context of oppression, Frankfurt Scholars initiated questions about social injustice and social structures, and this led to conscientisation of the general populace on the need to challenge oppressive structures. In this case, we attempt to use CER to conscientise school stakeholders to question social relations and to investigate the extent of relational structures in schools and the way these school structures contribute to social justice. We advocate for the interrogation of school structures through the lens of social justice because social justice has the impetus to promote human good, provide basic human needs, guarantee the protection of human rights, and promote the integral development of all the people of the globe (Ogbonnaya, 2012).

The social injustices that propel school violence include the unfair treatment of learners and educators, unfair distribution of school resources, insensitivity to gender, and discriminatory racial statements that degrade learners, educators, and certain races. Furthermore, some educators, as claimed by Mncube and Harber (2013), are domineering and authoritarian rather than democratic, thereby creating tense school relations that have the potential to escalate into school violence. Engaging social justice under such circumstances, as suggested by Gerson and Opotow (2004), provides a challenge to the powerful, to inadequate and unfair resource distribution, and to power disparities. The challenge should not be addressed haphazardly, instead, CER can provide "societies with common languages through which to address people's hopes and discontents" (Mendieta, 2005, p. 80). The CER approach can lead to violence being reduced significantly in schools. In this regard, we agree with Nkoane (2010, pp. 113-114) that, to create safer schools, we have to be "opposed to any classroom practices that undermine the rights of learners. In other words, in light of social justice, we maintain a particular focus on the critical pedagogy principles such as dialogue and dialectic voice."

The second principle of CER we discuss is social transformation as it relates to corporal punishment.

\section{Transforming schools to end corporal punishment.}

The Frankfurt Scholars were committed to ensuring that oppressive social structures were challenged and replaced with emancipatory structures that have respect for humanity. Social transformation, as proposed by Brooke (2002, p. 49), not only "picture[s] insufficiencies in society but also . . . encourage[s] reflection upon" and liberation from any shortfalls toward igniting a desirable change. It attempts "to name reality, articulate how social reality functions and decide how issues are organised and defined" (McLaren, 1995, p. 272) with the goal of change for the better. Thus, informed by CER, we problematise corporal punishment and suggest how relations can be tailored to eliminate the use of force against learners and teachers, or anyone else in the school milieu. Corporal punishment, despite being forbidden, continues to be used in most South African schools. Learners respond to corporal punishment through various means such as attacking educators or engaging in truancy in protest of the use of corporal punishment. Commenting on corporal punishment, Mthethwa, a KwaZulu-Natal Member of the Executive Committee (2016, cited in Pyatt, 2017, p. 1), stated:

The department was concerned that teachers continue to "dish out" corporal punishment despite it being banned more than 20 years ago... Children have the right to be free from all forms of violence, to enjoy their education, and not to be treated or punished in a cruel, inhumane, and degrading way.

Mncube and Harber (2013) argued that applying corporal punishment is indeed unprofessional, and that it aggravates violence in schools. Furthermore, aggression, as displayed by some teachers, appears 
to be particularly problematic (Davids \& Waghid, 2016). For example, Vilakazi (2017) reported that an 11-year-old Grade 6 learner was found hanging from the ceiling of the garage at his home, wearing his school uniform. He had killed himself because he was afraid of his mathematics teacher, who, the learner may have believed, was going to administer corporal punishment. Leoschut and Bonora (2007) believe that corporal punishment exposes and reinforces aggression and contributes to society becoming more violent. We problematise the use of corporal punishment because it leads to "prejudices, terror, intolerance, exclusion and, above all, the rejection of any dialogue" (Preis \& Russell, 2006, p. 14); it does not correlate with democracy, which can usher in school safety. Corporal punishment no longer yields the desired response in school discipline, yet, some teachers remain persuaded that it is necessary for school discipline. The situation is exacerbated by the fact that some communities and churches encourage the use of corporal punishment (Morrell, 2001).

The critical question facing scholars and educationists is: What could replace corporal punishment as a means to instil school discipline? In responding to this question, we refer to CER and propose that school discipline can be achieved through dialogues with relevant learners. One-to-one dialogue with learners should be guided by respect and justice rather than domination, negativity, and prejudice. Once the learners experience that they are treated as people with voices and rights in the school setup, their aggression will be reduced, and mutual understanding about educational practices elevated (Mnube \& Harber, 2013). Connolly (2015, pp. 395-396) advised that healthy relations have the impetus to "diagnose social pathology caused by the contemporary structure of school violence . . . [and] establish an intrapsychic foundation for the struggle for recognition which pushes beyond conventional norms." Not all educators find it easy to enter into dialogue with learners; however, dialogue is desirable and possible. Through this praxis, change is inevitable and could improve school conditions (Kreber, 2005).

\section{Elimination of false consciousness in school violence narratives.}

The elimination of false consciousness is traced to the work of Foucault and Freirean critical pedagogy; it states that ideology must allow individuals and groups to critique and resist oppressive regimes of power, thereby eliminating false consciousness (as in McKernan, 2013). This principle "attempts to expose and questions hegemony, traditional power assumptions held about relationships, groups, communities, societies, and organisations to promote social change" (Given, 2008, p. 140). It "aims at solving practical problems by critical thinking and the use of knowledge which is free from superstition and prejudice" (Steinvorth, 2008, p. 400). In doing so, as stipulated by Mahlomaholo (2009), CER places value on deep analysis as opposed to generalisation and broad, sweeping statements on school violence. Thus, deep analysis has the impetus to empower and change people's lives and stations in life, liberating them from less useful practices and thoughts and meeting the needs of real-life situations (Mahlomaholo, 2009). Eliminating false consciousness, according to Horkheimer and Adorno (1989), is geared to castigate domination, which distorts consciousness, controls practice, and directs discourses, leaving people without the possibility of either discovering anything that is already posited in the dominant ideology, or understanding anything except through prescribed epistemologies, practices, and discourses. Narrowing this tenet to the school violence narrative, we raise two matters. First, we submit that some educators play a considerable role in exacerbating school violence (Mncube \& Harber, 2013; Maphosa \& Shumba, 2010; Mthinyane, 2013) and, second, that there is a need to eliminate the perception that learners are the only victims of school violence-a perception that negates the fact that educators are also victims. By the elimination of false consciousness as used in this paper, we mean a false belief that it is certain section of the society that causes school violence. Again, this is a simplistic approach to school violence that does not cater for all variables in school violence. To develop this further, we will deal with these two aspects as we develop our argument. 
First, some educators are also responsible for causing school violence, hence, efforts to address school violence only from learners' perspectives are inadequate. Doing so defeats measures that address school violence holistically. Unprofessional activities by teachers such as high absenteeism, failure to mark books, entering into sexual relationships with learners, applying corporal punishment, drinking with learners, and improper dress, among other transgressions, can contribute to school violence. Thus, failure by teachers to execute their professional goals can trigger unpleasant responses such as strikes and violence against property and educators. Thus, it is important that educators maintain high standards of professionalism by exhibiting, as proposed by Hutchings (2016), a caring demeanour and the ability to address the needs of the learners through nonviolent means such as dialogue.

Second, there is need to eliminate the false consciousness that claims that learners are the only victims of school violence. Educators are also victims (Fengu, 2017; Nthate, 2017). Several reports of teachers as victims exist, among them: the killing of a Bosele middle-school teacher in the Northern Cape; the assault of a teacher by a Grade 8 learner in Sasolburg, who used a broom; and a 15-year-old boy allegedly wounding a teacher and attempting to shoot the deputy principal (Tau, 2013). In 2017, a deputy principal was shot dead at Edalinceba Primary School in Nigel during school-related disturbances (Magwedze, 2017); the killing happened within the school grounds, which traumatised learners and other educators. The deaths of these teachers highlight a dimension of school violence that is not discussed often enough (Benbow, 2013). In some cases, teachers resign because they fear being victimised by learners and colleagues (Child, 2017).

Unfortunately, in some cases, parents are also guilty of inciting violence against teachers (Tau, 2013); parents' involvement in school violence has not been dealt with extensively either. Few school violence narratives problematise this aspect because of the false consciousness that assumes learners are the only victims. By acknowledging that teachers are victims of school violence, we can start applying an holistic approach to ending school violence-which will help to frame relations through respect, justice, and love. We should acknowledge that all school stakeholders can be either perpetrators or victims of school violence. We also concur with the current minister of Basic Education's (DBE, 2016) sentiments that parents and communities can help solve the problem of school violence. Finally, CER assumes that people involved are both empowered and ideally placed to understand the problem and, most importantly, find and enact solutions for the problem.

\section{Significance of the Argument}

The strength of this article is that it engages with theory in attempting to develop a strategy to mitigate school violence in South Africa. While various articles have proposed solutions to school violence, we believe this article is unique because it theorises school violence through the lens of CER and transforms some of its tenets into possible solutions for school violence. Another strength is that it calls for transformation, not only of learners' perspectives but also of that of teachers, with the aim of changing people's hearts and minds and liberating people from violent behaviour (Tshelane \& Tshelane, 2014). The article argues that the teacher element in school violence narratives has not been problematised adequately; teachers play a significant role in school violence narratives. We hope that, through this paper, school-based solutions that draw on the experiences and contributions of everyone within the school body (Centre for Justice and Crime Prevention, 2013) will be enacted-solutions that emphasise social justice, dialogue, and mutual respect. However, the weakness of the article is the failure to articulate how CER principles can be infused in every teacher, learner, and community member, to create safer schools. On the other hand, this weakness gives space for other scholars of school violence discourses to investigate further. The article may be seen to be addressed to intellectuals, leaving behind others; in other words, some victims of violence who lack basic knowledge of transformational education theories may not benefit. CER, as argued by Scotland (2012), does not postulate that different contributors engage in research with fluctuating levels of conscientisation; CER 
assumes that people on the ground are ready to accept and practise social justice and social transformation, and eliminate false consciousness. The reality is that not everyone is ready to frame social relations in CER to mitigate school violence, thus, one of the efforts to address school violence should involve presenting workshops between teachers and learners, as part of the curriculum, to focus on topics such as conflict resolution, social justice, and learner and teacher professionalism.

\section{Conclusion}

The article attempts to contribute to an ongoing debate about how to improve dialogue between stakeholders in schools. In doing so, we argue that if relations are framed in social justice, social transformation, and the elimination of false consciousness, there is a possibility of achieving safe schools. We also argue that if these three principles underpin school relations, there is a good likelihood that school violence will be mitigated. The paper teases and invites other scholars to suggest other ways that can lead to reduction of school violence. Through this, we contribute to making the world and, in particular, schools better places for everyone.

\section{Acknowledgement}

The financial assistance of the National Research Foundation (NRF) towards this research hereby acknowledged. Opinions expressed and conclusions arrived at are those of the authors and are not necessarily to be attributed to the NRF.

\section{References}

Abramovay, M., \& Gracas Rua, M. D. (2002). Violences in schools. Brasilia, Brazil: Unesco.

Abu-Nimer, M., Khoury, A., \& Welty, W. (2007). Unity in diversity in the Middle East: New York, USA: United State Institute of Peace Press.

Akinsola, H. A. (2010). Understanding the determinants and preventative strategies for high school violence in South Africa: The stakeholders' targeted model. African Journal for Physical Health Education, Recreation and Dance, 16(4), 648-665.

Argyris, C., \& Schön, D. (1974). Theory in practice: Increasing professional effectiveness. San Francisco, USA: Jossey Bass.

Benbow, C. (2013, December 5). Teachers often victims of violence. Vanderbilt University. Retrieved from https://my.vanderbilt.edu/camillabenbow/news/teachers-often-victims-of-violence/

Brady, J. A. (2010). A burning desire for social justice. Religious Education, 105(1), 8-11.

Brooke, C. (2002). What does it mean to be critical in IS research? Journal of Information Technology, $17,49-55$.

Burton, P., \& Leoschut, L. (2013). School violence in South Africa: Results of the 2012 national school violence study. Cape Town, South Africa: Centre for Justice and Crime Prevention.

Carlisle, L. R., Jackson, B. W., \& George, A. (2006). Principles of social justice education: The social justice in school project. Equality and Excellence in Education, 39(1), 55-64.

Centre for Justice and Crime Prevention. (2013, April 17). 22\% of children experienced some form of violence at school: Study. Sowetan Live. Retrieved from https://www.sowetanlive.co.za/news/2013-04-17-22-of-children-experienced-some-form-ofviolence-at-school-study/

Chawane, G. (2018, June 12). Pupils beating up their teachers in South Africa. The Citizen. Retrieved from www.citizen.co.za/news/southafrica/1951413/videos-pupils-beating-up-their-teachers-in-sa 
Chidarikire, M. (2017). A peer counselling strategy for alleviating drug abuse in Zimbabwean rural ecologies (Unpublished doctoral thesis). University of the Free State, South Africa.

Child, K. (2017, June 15). Schools are so violent teachers live in fear. Times Live. Retrieved from https://www.timeslive.co.za/news/south-africa/2017-06-15-schools-are-so-violent-teachers-livein-fearl

Connell, R. (2012). Just education. Journal of Education Policy, 25(5), 681-681.

Connolly, J. (2015). A fourth order of recognition? Critical Horizons, 16(4), 393-410.

Davids, N., \& Waghid, Y. (2016). Responding to school violence in post-apartheid schools on social leadership as mutual engagement. Education as Change, 20(1), 28-42.

de Clercq, F. (2013). Professionalism in South Africa education: The challenges of developing teacher professional knowledge, practice, identity and voice. Journal of Education, 57, 31-53.

Demirovic, A. (2009, July). Foucault, Gramsci and critical theory: Remarks on their relationship Presentation at Workshop 2: Foucault and critical realism: Marx, Gramsci and Foucault, at the Cultural Political Economy Research Cluster of the Institute for Advanced Studies of Lancaster University. Retrieved from www.lancaster.ac.uk/cperc/docs/CR-Demirovic-Foucault.pdf

Department of Basic Education (2016). Annual report on school discipline. Bloemfontein, South Africa: Department of Basic Education.

Dilworth-Anderson, P., Pierre, G., \& Hilliard, T. S. (2012). Social justice, health disparities and culture in the care of the elderly. Journal of Law, Medicine \& Ethics, 40(1), 26-32.

Dube, B. (2016). A socio-religious hybridity strategy to respond to the problems of religious studies in Zimbabwe (Unpublished doctoral thesis). University of the Free State, South Africa.

Dlamini, P. (2018a, March 16). Violence in schools is under-reported, says teachers' association. Sunday Times. Retrieved from https://www.timeslive.co.za/news/south-africa/2018-03-16violence-in-schools-is-under-reported-says-teachers-association/

Dlamini, P. (2018b, March 16). Parents to blame for children's behaviour, says schools federation. Sunday Times. Retrieved from https://www.timeslive.co.za/news/south-africa/2018-03-16parents-to-blame-for-childrens-behaviour-says-schools-federation/

Edberg, M., Shaikh, H., Rimal, R. N., Rassool, R., \& Mthembu, M. (2017). Development of a communication strategy to reduce violence against children in South Africa: A social-ecological approach. The African Journal of Information and Communication (AJIC), 20, 49-76.

Eisenbraun, K. D. (2007). Violence in schools: Prevalence, prediction and prevention. Aggression and Violent Behaviour, 12(2007), $429-469$.

Fengu, M. (2017, December 10). Kids versus teachers. News24. Retrieved from https://www.news24.com/SouthAfrica/News/kids-versus-teachers-20171210

Francia, G., \& Edling, S. (2017). Children's rights and violence: A case analysis at Swedish boarding school. Childhood, 24(1), 51-67.Gerson, J. K., \& Opotow, S. (2004). Deadly conflict and challenges of coexistence. Analysis of Social Issues of Public Policy, 4(1), 265-268.

Gittins, C. (2006). Violence reduction in schools: How to make a difference? Strasbourg, France: Council of Europe.

Given, L. M. (Ed.). (2008). The SAGE encyclopaedia of quantitative research methods (1 \& 2). London, UK: SAGE.

Gomes, C. A., \& Pereira, M. M. (2007). Teacher education in face of violence from/at schools. Cadernos de Pesquisa, 39(136). 
Grobler, G. W. (2018). Narratives of the teachers' experiences of school violence and ethics of care (Unpublished master's thesis). Stellenbosch University, South Africa.

Hackman, H. W. (2005). Five essential components for social justice. Equity and Excellence in Education, 38, 103-109.

Head, T. (2018, March 9). Questions raised as high school teacher abused by learner. The South African. Retrieved from https://www.thesouthafrican.com/gauteng-high-school-teacher-abuse/

Horkheimer, M., \& Adorno, T. (1989). The dialectics of enlightenment. London, UK: Verso.

Hutchings, T. (2016). Protecting the profession: Professional ethics in the classroom. RealClearPolitics. Retrieved from https://www.ets.org/s/proethica/pdf/real-clear-articles.pdf

Hweshe, F. (2011, April 13). Minister worried about school violence. South African Government News Agency. Retrieved from https://www.sanews.gov.za/south-africa/minister-worried-about-schoolviolence

Jordaan, N. (2018, June 12). Violence in SA schools-by pupils against teachers. Business Day. Retrieved from https://www.businesslive.co.za/bd/national/2018-06-12-violence-in-sa-schools--by-pupilsagainst-teachers/

Kaur, B. (2012). Equality and social justice in teaching and teacher education. Teaching and Teacher Education, 28, 485-492.

Kindiki, J. N. (2009). Effectiveness of communication on students discipline in secondary schools in Kenya. Educational Research and Review, 4(5), 252-259.

Kingston, D. (2007). Empirical or critical communication research. Communication South Africa, Journal for Communication Theory and Research, 41(1), 32-47.

Kreber, C. (2005). Charting a critical course on the scholarship of university teaching discourse. Acta Academica, 43(4), 111-126.

Langhout, R. D., \& Annear, L. (2010). Safe and unsafe school spaces: Comparing elementary school student perceptions to common ecological interventions and operationalization. Journal of Community \& Applied Social Psychology, 2010. Retrieved from https://ccrec.ucsc.edu/sites/default/files/langhout annear 2010.pdf

Lazarus, S., Khan, N., \& Johnson, B. (2012). Towards safer schools. In A. van Niekerk, S. Suffla, \& M. Seedat (Eds.), Crime, violence and injury in South Africa: Enabling child safety (pp. 134-147). Tygerberg, South Africa: Medical Research Council.

Leoschut, L., \& Bonora, A. (2007). Offender perspectives on violent crime. In P. Burton (Ed.), Someone stole my smile: An exploration into the causes of youth violence in South Africa (pp. 89-112). Cape Town, South Africa: Centre for Justice and Crime Prevention.

Magwedze, H. (2017, September 28). Violence in South African schools has reached a critical point. EWN, Eyewitness News. Retrieved from http://ewn.co.za/2017/09/28/violence-in-sa-schools-hasreached-a-critical-point

Mahlomaholo, S. (2009). Critical emancipatory research and academic identity. Africa Education Review, 6(2), 224-237.

Malcolm, C., Motala, E., Motala, S., Moyo, G., Pampallis, J., \& Thayer, B. (Eds.). (2007). Democracy, human rights and social justice in education. Bloemfontein, South Africa: Centre for Educational Policy Development.

Maphosa, C., \& Shumba, A. (2010). Educators' disciplinary capabilities after banning of corporal punishment in South African schools. South African Journal of Education, 30(2010), 387-399. 
Mashaba, S. (2018, January 16). Grade 8 pupil accused of killing over failure. IOL News. Retrieved from https://www.iol.co.za/news/south-africa/gauteng/grade-8-pupil-accused-of-killing-teacher-overfailure-12742285

McDonald, Z. (2013). Interrupting school violence with deliberate encounters. South African Review of Sociology, 45(3), 20-33.

McKernan, J. A. (2013). The origins of critical theory in education: Fabian socialism as social reconstructionism in nineteenth century Britain. British Journal of Educational Studies, 61(4), 417433.

McLaren, P. L. (1995). Collision with otherness: "Travelling"theory, post-colonial criticism, and the politics of ethnographic practice-the mission of the wounded ethnographer. Critical Theory and Educational Research, 3, 271-300.

McLaughlin, N. (1999). Origins myths in the social sciences: Fromm, the Frankfurt School and the emergence of critical theory. Canadian Journal of Sociology, 24(1), 109-139.

Mendieta, E. (Ed.). (2005). The Frankfurt School on religion: Key writing by the major thinkers. New York, USA: Routledge.

Mncube, V. S., \& Harber, C. (2013). Learners' democratic involvement in school governing bodies in South Africa: Making the voice of the voiceless heard. SA-eDuc Journal, 10(1), 1-24.

Moen, M., \& Steyn, M. (2016). Young children's experiences of violence: Baby steps to a safer South Africa. Pretoria, South Africa: University of Pretoria.

Morrell, R. (2001). Corporal punishment in South African schools: A neglected explanation for its persistence. South African Journal of Education, 21(4), 292-299.

Msimanga, M. R. (2017). Teach and assess: A strategy for effective teaching and learning in economic and management sciences (Unpublished doctoral thesis). University of the Free State, South Africa.

Mthinyane, S. E. (2013). Dynamics of school based violence: Exploring school governing bodies in postconflict South African schools (Unpublished doctoral thesis). University of KwaZulu-Natal, South Africa.

Ncontsa, V. N., \& Shumba, A. (2013). The nature, causes and effects of violence in South African high schools. South African Journal of Education, 33(3), 1-15.

Ndlovu-Gatsheni, S. J. (2013). Why decoloniality in the 21st century? The Thinker for Thought Leaders, $48,10-16$.

Ngqela, N., \& Lewis, A. (2012). Exploring adolescent learners' experiences of school violence in a township high school. Child Abuse Research: A South African Journal, 13(1), 87-97.

Ngwenyama, O. K. (1991). The critical social theory approach to information systems: Problems and challenges. In H-E. Nissen, H. K. Klein, \& R. A. Hirschheim (Eds.), Information systems research: Contemporary approaches and emergent traditions (pp. 267-280). Amsterdam, Netherlands: NorthHolland.

Nkoane, M. M. (2010). Critical liberatory, inclusive pedagogy: Arguing for a zero defect. Acta Academica, 43(4), 111-126.

Nkoane, M. M. (2012). Critical emancipatory research for social justice and democratic citizenship. Perspectives in Education, 30(3), 98-104.

Nkoane, M. M. (2013). Creating sustainable postgraduate supervision learning environments through critical emancipatory research. TD: The Journal of Transdisciplinary Research in Southern Africa, 9(3), 393-400. 
Nthate, P. (2017, August 28). School violence: How can we make the classroom a safe haven for learning. Daily Maverick. Retrieved from https://www.dailymaverick.co.za/article/2017-08-28school-violence-how-can-we-make-the-classroom-a-safe-haven-for-learning

Ogbonnaya, J. (2012). Theology, culture and sustainable development in Africa. ACUHIAM Journal, 3, 1-30.

Preis, A. B., \& Russell, F. (Eds.) (2006). Dialogue among civilizations: Regional summit on inter-religious and inter-ethnic dialogue. Tirana, Albania: Unesco.

Pyatt, J. (2017, September 12). Girls screams in agony as teacher brutally beats her with cane while other pupils laugh and jeer. MailOnline. Retrieved from https://www.dailymail.co.uk/news/article4875386/Girl-screams-agony-teacher-brutally-beats-her.html

SADTU (South African Democratic Teachers Union). (2018). SADTU statement on the 2018/2019 Basic Education budget vote. Retrieved from http://www.sadtu.org.za/content/sadtu-statement20182019-basic-education-budget-vote

Schmidt, J. (2007). The eclipse of reason and the end of the Frankfurt School in American schools. American Educational Research Journal, 33, 757-798.

Scotland, J. (2012). Exploring the philosophical underpinnings of research: Relating ontology and epistemology to the methodology and methods of scientific interpretive and critical research paradigms. English Language Paradigms, 5(9), 9-16.

Sinnerbrink, R. (2012). Critical theory as disclosing critique: A response to Kompridis. Constellations, 19(3), 370-381.

Steinvorth, U. (2008). On critical theory. Analyse \& Kritik, 30, 399-423.

Stoddard, E. D. (2017, May 21). Deputy President Ramaphosa says South Africa must avoid "mafia state" fate. Reuters. Retrieved from https://www.reuters.com/article/us-safrica-politics/deputypresident-ramaphosa-says-south-africa-must-avoid-mafia-state-fate-idUSKBN18HORT

Strydom, T. J. (2017, May 23). Churches warn South Africa becoming a "mafia state." Reuters. Retrieved from https://www.reuters.com/article/safrica-politics/churches-warn-south-africa-becoming-amafia-state-idUSKCN18F142

Tau, S. (2013, September 23). Violence in South African schools a "serious problem" - unions. The Citizen. Retrieved from https://citizen.co.za/news/south-africa/51477/violence-in-sa-schools-aserious-problem-unions/

Traitler, R. (2015). Mission on the move for justice and peace: The case of the European project for interreligious learning. International Review of Mission, 104(1), 83-90.

Tshelane, E., \& Tshelane, M. (2014). Enhancing teachers' professional curriculum practice in sex education in a Grade 10 life orientation class. Journal of Educational and Social Research, 4(6), 287294.

van der Westhuizen, C. N., \& Maree, J. G. (2009). The scope of violence in a number of Gauteng schools. Acta Criminologica, 22(3), 43-62.

Vilakazi, Z. (2017, August 4). Boy hangs himself. Daily Sun. Retrieved from https://www.dailysun.co.za/News/National/boy-hangs-himself-20170803

Wellmer, A. (2014). On critical theory. Social Research: An International Quarterly, 81(3), 705-733.

Wicks, J. (2015, July 21). KZN pupils killed in suspected gang fight at school. News24. Retrieved from https://www.news24.com/SouthAfrica/News/KZN-pupil-killed-in-suspected-gang-fight-at-school20150721 
Wicks, J., Olifant, N., \& Naidoo, Y. (2017, September 11). New school corporal punishment video emerges. Times Live. Retrieved from https://www.timeslive.co.za/news/south-africa/2017-09-11watch--new-school-corporal-punishment-video-emerges/ 